\title{
Extracorporeal shock wave lithotripsy in the treatment of renal and ureteral stones
}

Fábio César Miranda Torricelli ${ }^{1 *}$, Alexandre Danilovic ${ }^{1}$, Fábio Carvalho VicentinI ${ }^{1}$, Giovanni Scala Marchini ${ }^{1}$, Miguel Srougi ${ }^{2}$,

\section{EduARDo MAZZUCCHI ${ }^{3}$}

${ }^{1}$ Assistant Physician to the Endourology Group at the University of São Paulo Medical School's Hospital das Clínicas (HC-FMUSP), São Paulo, SP, Brazil 2Full Professor of Urology at the HC-FMUSP

${ }^{3}$ Post-doctoral Professor, Head of the Endourology and Lithiasis Group at the HC-FMUSP

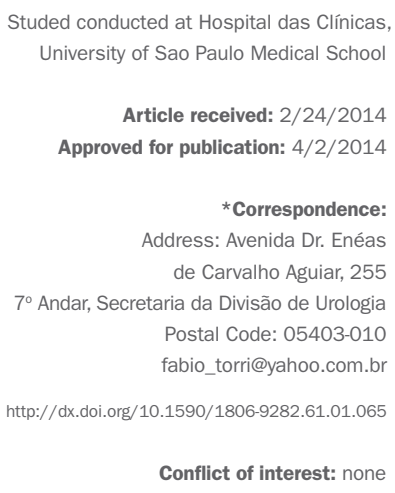

\section{SUMmARY}

The use of certain technical principles and the selection of favorable cases can optimize the results of extracorporeal shock wave lithotripsy (ESWL). The aim of this study is to review how ESWL works, its indications and contraindications, predictive factors for success, and its complications. A search was conducted on the Pubmed ${ }^{\circledR}$ database between January 1984 and October 2013 using "shock wave lithotripsy" and "stone" as key-words. Only articles with a high level of evidence, in English, and conducted in humans, such as clinical trials or review/ meta-analysis, were included. To optimize the search for the ESWL results, several technical factors including type of lithotripsy device, energy and frequency of pulses, coupling of the patient to the lithotriptor, location of the calculus, and type of anesthesia should be taken into consideration. Other factors related to the patient, stone size and density, skin to stone distance, anatomy of the excretory path, and kidney anomalies are also important. Antibiotic prophylaxis is not necessary, and routine double J stent placement before the procedure is not routinely recommended. Alpha-blockers, particularly tamsulosin, are useful for stones $>10 \mathrm{~mm}$. Minor complications may occur following ESWL, which generally respond well to clinical interventions. The relationship between ESWL and hypertension/diabetes is not well established.

Key-words: lithotripsy, renal colic, ureter, urinary calculi, kidney calculi.

\section{INTRODUCTION}

Extracorporeal shock wave lithotripsy (ESWL) was introduced into medical practice in the 1980s, and since then has become one of the main treatment options in patients with renal and/or ureteral calculi. However, the progress of endourology and minimally invasive surgeries with their high success rates has reduced its applicability. From then on, it has become necessary to search for the optimal technical parameters and careful selection of candidates for ESWL in order to optimize its results and justify its indication. The aim of this study is to review how ESWL works, its indications and contraindications, predictive factors for success, and its early and late complications.

\section{Methods}

A search was conducted on the Pubmed ${ }^{\circledR}$ database between January 1984 and October 2013 using "shock wave lithotripsy" and "stone" as keywords in the title or summary, resulting in 2,299 articles. This review only considered articles written in English and conducted in humans, including "clinical trials", "reviews" or "meta-analyses", in a to- 
tal of 428 studies, excluding duplicates. The summaries of these articles were assessed by two independent authors in order to select the studies with the best level of evidence in each theme covered during the review. Articles on specific and relevant topics without a level of evidence over II were also included (Figure 1).

\section{TECHNICAL PRINCIPLES}

ESWL consists of the fragmentation of calculi by means of pulsed acoustic waves at high intensity and low frequency directed at the stone from an external power source to the patient, called a lithotriptor. To optimize the results of ESWL, several technical factors must be taken into consideration, such as the type of device, ${ }^{1}$ the energy level, the frequency of the pulses, the quality of coupling between patient and lithotripsy machine, the focal zone, the site of the calculus, and anesthetic technique.

The procedure should start with a low energy level $(13-14 \mathrm{KV})$ in each pulse, which is then gradually increased. ${ }^{2}$ The successive shock waves result in direct shearing forces, as well as in the formation of cavitation bubbles around the stone, which when ruptured generate energy that enhances the fragmentation of the calculus. ${ }^{3}$ Currently, frequencies from 60-90 shocks/minute have been chosen, with a gradual increase in energy with the aim of increasing the fragmentation of the stone and reducing the morbidity of the procedure. ${ }^{4,5} \mathrm{~A}$ recent meta-analysis proved the superior efficacy of ESWL with a frequency of 60 in relation to 120 shocks per minute. ${ }^{4}$ And as demonstrated by Pace et al., ${ }^{6}$ this benefit is clearest in calculi over $10 \mathrm{~mm}$.

The correct coupling of patients to lithotripsy machines increases the success of ESWL. The presence of air in the path of the shock waves is inversely proportional to its effectiveness. ${ }^{7-9}$ The focal zone has also been investigated to optimize the delivery of shock waves, with current recommendations for a larger focal zone $(50 \times 9 \mathrm{~mm})$ for renal calculi and a smaller one $(28 \times 6 \mathrm{~mm})$ for ureteral ones. ${ }^{3}$

The preparation of the patient consists of an appropriate assessment before the procedure, using non-contrast spiral computed tomography as the investigation of choice, as it provides fundamental information regarding indication and prognosis..$^{10}$ Coagulation profiles and urine cultures should be checked prior to the procedure. The patient usually remains in a supine position, but in cases of distal ureter calculi, horseshoe kidney or pelvic kidney, changing to a ventral position generates a better "window", free from the iliac crest. According to the size, density and location of the calculus, its identification is made either by fluoroscopy or ultrasound. The latter method has the advantages of not using ionizing radiation and a greater sensitivity in the characterization of low

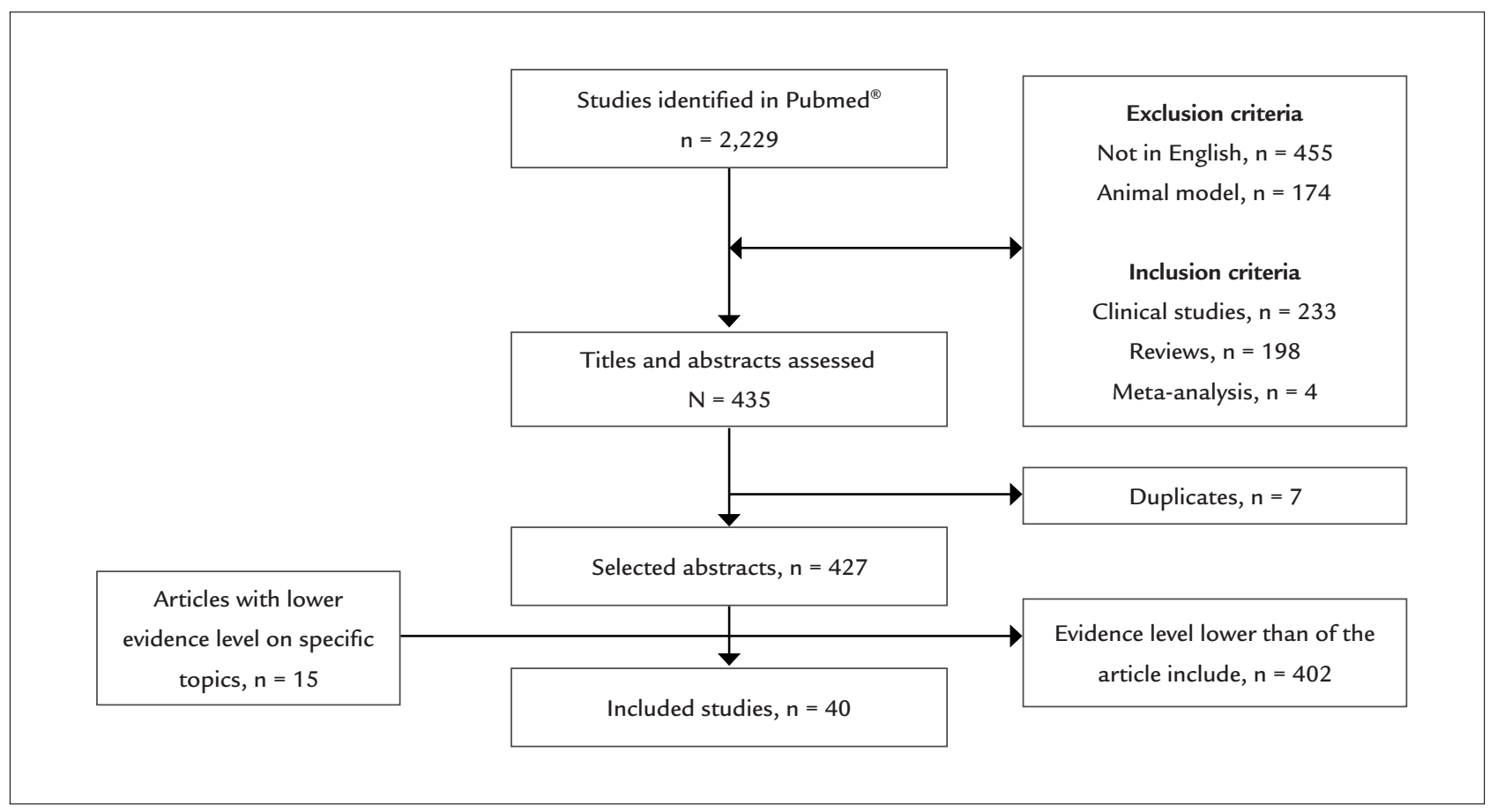

FIGURE 1 Flowchart for the identified, selected and/or excluded studies in the review. 
density renal and ureteral stones. The exact location of the calculus is essential to the success of ESWL, so that the use of high frequency ventilation with low current volume to reduce breathing movements is a valid alternative. ${ }^{11,12}$ Increasing the focal zone or the use of automated tracking systems via fluoroscopy also help the correct delivery of shock waves on the calculus. ${ }^{3}$ After general anesthesia, which is preferred owing to better results, ${ }^{13}$ or sedation, the procedure can begin. In most services, about 3,000 pulses are applied, with a total procedure time of around 1 hour.

Table 1 summarizes the technical factors and their respective levels of evidence/grade of recommendation impacting the ESWL results.

\section{Indications}

Currently, ESWL is considered a first-line treatment for renal calculi under $2.0 \mathrm{~cm}$, with a success rate ranging from 33 to $91 \% .{ }^{14}$ Some series have already reported the use of ESWL for calculi over $2.0 \mathrm{~cm}$, but the low success rates and the need for multiple sessions to optimize results are limiting factors. ${ }^{14}$ Owing to its low invasiveness, ESWL is also recommended in the use of ureteral calculi..$^{15} \mathrm{~A}$ recent meta-analysis demonstrated that emergency ESWL for ureteral calculi presents an overall stone-free rate of $78 \%$ (75-82\%), with $79 \%$ (61-95\%) in proximal ureter calculi,
$78 \%(69-88 \%)$ in mid ureter calculi and $79 \%(74-84 \%)$ in distal ureter calculi. ${ }^{16}$

\section{Contraindications}

The formal contraindications for ESWL are: pregnancy, untreated urinary tract infection/urosepsis, decompensated coagulopathy, uncontrolled arrhythmia, and abdominal aortic aneurysm $>4.0 \mathrm{~cm} .{ }^{17}$ In the presence of any of these conditions, other treatment methods should be proposed.

\section{Predictors of success}

A series of factors can influence the results of ESWL, especially factors related to the calculus (size, location, composition-density), factors related to renal anatomy (obstruction/stasis, hydronephrosis, stenosis of the ureteropelvic junction, calyceal diverticula, horseshoe kidney, ectopic kidney/renal fusion) and patient-related factors (obesity, skin to stone distance, renal failure).

ESWL presents results inversely proportional to the size of the calculus. A meta-analysis published on 1994 by Lingeman et al. ${ }^{14}$ demonstrated that ESWL has a success rate of 74, 56 and $33 \%$ for kidney stones up to $1.0 \mathrm{~cm}, 1.0$ to $2.0 \mathrm{~cm}$ and greater than $2.0 \mathrm{~cm}$, respectively.

Various articles have been published studying predictors of the success of ESWL. Al-Ansari et al. ${ }^{18}$ in a retrospective study of 427 patients with calculi up to $3.0 \mathrm{~cm}$ un-

\begin{tabular}{|c|c|c|c|c|c|}
\hline Factor & Evidence & Study type & $\begin{array}{l}\text { Level of } \\
\text { evidence }\end{array}$ & $\begin{array}{l}\text { Grade of } \\
\text { recommendation }\end{array}$ & Authors \\
\hline $\begin{array}{l}\text { Lithotripsy } \\
\text { device }\end{array}$ & $\begin{array}{l}\text { There is no difference between } \\
\text { lithotripters (electrohydraulic, } \\
\text { electromagnetic or piezoelectric) in the } \\
\text { treatment of kidney stones }\end{array}$ & Case control & III & B & Alanee $\mathrm{S}^{1}$ \\
\hline Energy & $\begin{array}{l}\text { Start with low energy and increase } \\
\text { gradually }\end{array}$ & $\begin{array}{l}\text { Prospective, } \\
\text { randomized }\end{array}$ & $\mathrm{lb}$ & A & Lambert $\mathrm{EH}^{2}$ \\
\hline $\begin{array}{l}\text { Frequency of } \\
\text { pulses }\end{array}$ & $\begin{array}{l}\text { A lower frequency }(60 \mathrm{~Hz}) \text { performs better } \\
\text { than the high frequency }(120 \mathrm{~Hz})\end{array}$ & $\begin{array}{l}\text { Meta-analysis of } \\
\text { randomized clinical } \\
\text { studies }\end{array}$ & la & A & $\mathrm{Li} \mathrm{K}^{4}$ \\
\hline Coupling & $\begin{array}{l}\text { The presence of air in the path of the } \\
\text { shock wave negatively affects the results } \\
\text { of ESWL }\end{array}$ & $\begin{array}{l}\text { In vitro study/Series of } \\
\text { cases }\end{array}$ & III & B & $\begin{array}{l}\text { Pishchalnikov } \mathrm{YA}^{7} \\
\text { and Jain } \mathrm{A}^{8} / \mathrm{Li} \mathrm{G}^{9}\end{array}$ \\
\hline $\begin{array}{l}\text { Location of } \\
\text { the calculus }\end{array}$ & $\begin{array}{l}\text { Kidney movements during respiration } \\
\text { negatively affect ESWL. High frequency } \\
\text { ventilation can optimize the results }\end{array}$ & $\begin{array}{l}\text { Retrospective cohort } \\
\text { study }\end{array}$ & III & B & $\begin{array}{l}\text { Warner } \mathrm{MA}^{11} \text { and } \\
\text { Cormack JR }\end{array}$ \\
\hline Anesthesia & $\begin{array}{l}\text { General anesthesia shows better results } \\
\text { than sedation }\end{array}$ & $\begin{array}{l}\text { Retrospective cohort } \\
\text { study }\end{array}$ & III & B & Sorensen $C^{13}$ \\
\hline
\end{tabular}


dergoing ESWL reported a success rate (defined as patients free of calculi or fragments under $4 \mathrm{~mm}$ ) of $78 \%$ in three months, while $53.1 \%$ of these required more than one session and $8.4 \%$ had treatment complemented by another procedure (percutaneous nephrolithotomy, flexible ureteroscopy or double-J stenting). In this study of cases, the size, location and number of calculi, as well as renal anatomy and congenital anomalies have an impact on the success rate. Calculi smaller than $10 \mathrm{~mm}$ had a rate of success of $90 \%$, while those larger than $10 \mathrm{~mm}$ presented a rate of $70 \%(\mathrm{p}<0.05)$. Calculi located in the renal pelvis and upper pole had a success rate of 87.3 and $88.5 \%$, respectively, while for lower pole calculi this was $69.5 \%$ ( $\mathrm{p}$ $<0.05$ ). Kidneys with a single calculus had a $78.3 \%$ success rate compared to $62.8 \%$ in multiple kidney calculi ( $\mathrm{p}<0.01$ ). Kidneys without dilation had an $83 \%$ success rate, while for kidneys with hydronephrosis success reached $76 \%$ $(\mathrm{p}<0.05)$. Kidneys without congenital anomalies had a success rate of $79 \%$ compared to $54 \%$ in kidneys with anomalies $(\mathrm{p}<0.03)$. In a larger study of cases encompassing 2,954 patients with calculi less than $3.0 \mathrm{~cm}$ undergoing ESWL, monotherapy with ESWL presented a stone-free rate of $86.7 \%$ at a 3 month follow-up. A logistic regression confirmed that size, location, number of calculi, renal anatomy and congenital disorders are predictors of success.

Some studies have analyzed the characteristics of the calculus and the patient. In a retrospective study with 111 patients with calculi under $2.0 \mathrm{~cm}$ submitted to ESWL, Perks et al. ${ }^{19}$ reported a stone-free rate of $40 \%$ and complete fragmentation in $24 \%$. The multivariate analysis including body mass index, size, location, attenuation, skin-to-stone distance (SSD) and composition of the calculation showed that the latter three factors were significantly and independently associated with elimination or complete fragmentation outcomes. Patients with favorable parameters had significantly better results than patients with unfavorable parameters $($ odds ratio $=7.1,95 \%$ confidence interval $=1.6$ to $32, \mathrm{p}=0.01$ ).

In an attempt to create a clinical nomogram for predicting the success of ESWL for renal and ureteral calculi, Wiesenthal et al. ${ }^{20}$ studied 422 patients with renal or ureteral calculi less than $2.0 \mathrm{~cm}$ in size. The success rate with a single session of ESWL was 70.2 and $60.3 \%$ for renal and ureteral calculi, respectively, in a 3 month follow-up. In logistic regression, patient age, calculus area and SSD were predictors of success of ESWL for renal calculi, while the body mass index and stone size were predictors of success of ESWL for ureteral calculi. In a similar study, Kanao et al. ${ }^{21}$ studied 435 patients with renal and ureteral calculi and developed a nomogram considering size, location (renal pelvis renal $v s$. renal calyx $v s$. proximal ureter $v$ s. distal ureter) and number of calculi as predictors of success. The highest success rate was obtained for single proximal ureteral calculi less than $5 \mathrm{~mm}$ (93.8\%) while the worst was for multiple calycine calculi larger than $21 \mathrm{~mm}$ (10.5\%).

There are few prospective studies evaluating the predictors of success of ESWL in renal calculi. A study on 120 patients with a single renal calculus between 0.5 and 2.5 $\mathrm{cm}$ undergoing ESWL showed good results on a three-month follow-up with computed tomography, with $87.5 \%$ of patients free of stones or with residual calculi less than $4 \mathrm{~mm}$. In this study, only the body mass index $(\mathrm{p}=0.04)$ and calculus densities greater than 1000 Hounsfield units $(\mathrm{p}=0.02)$ were predictors of success after the multivariate analysis. ${ }^{10}$

A topic still under debate regarding ESWL is its indication for lower calyx calculi, where renal anatomy, more precisely the infundibular calicinal angle, infundibular length, width and height can have a negative impact. $22-24$

Table 2 summarizes the main factors for poor prognosis in the success of ESWL, as well as the levels of evidence/grade of recommendation.

\section{ESWL adjuvant factors}

The use of antibiotics for ESWL in patients with sterile urine is not necessary. ${ }^{25} \mathrm{~A}$ meta-analysis involving nine studies with a total of 1,364 patients showed that antibiotic prophylaxis did not reduce the incidence of fever (RR 0,36 95\% CI 0.07-2.36, $\mathrm{p}=0.31$ ) and urinary infection (RR 0.54, 95\% CI 0.29-1.01, $\mathrm{p}=0.05$ ) (Level of evidence: $1 \mathrm{a}$; Grade of recommendation A).

Routine double-J stenting before ESWL does not increase the stone-free rate and does not reduce complications, and therefore should not be encouraged (Level of evidence: 1a; Grade of recommendation A). Even in patients with a single kidney the procedure without ureteral catheter is feasible, although it requires a careful selection of candidates. ${ }^{26} \mathrm{~A}$ systematic review, ${ }^{27}$ using sources such as the PubMed ${ }^{\circledR}$, Embase ${ }^{\circledR}$ and Cochrane databases evaluated the results and complications of ESWL in the treatment of calculi of the upper urinary tract with or without double-J stenting before the procedure. Rate of calculus-free response, steinstrasse, lower urinary tract symptoms, hematuria, fever, infection, pain, 
TABLE 2 Predictors of the success of extracorporeal shock wave lithotripsy

\begin{tabular}{|c|c|c|c|c|c|}
\hline Factor & Evidence & Study type & $\begin{array}{l}\text { Level of } \\
\text { evidence }\end{array}$ & $\begin{array}{l}\text { Grade of } \\
\text { recommendation }\end{array}$ & Authors \\
\hline $\begin{array}{l}\text { Size of the } \\
\text { calculus }\end{array}$ & Size is inversely proportional to the ESWL result & $\begin{array}{l}\text { Meta-analysis of } \\
\text { cohort studies }\end{array}$ & Ila & B & Lingeman J $\mathrm{E}^{14}$ \\
\hline $\begin{array}{l}\text { calculus } \\
\text { density }\end{array}$ & $\begin{array}{l}\text { High density calculi present worse results (>1000 } \\
\text { UH) }\end{array}$ & $\begin{array}{l}\text { Prospective } \\
\text { cohort study }\end{array}$ & IIb & B & El-Nahas $\mathrm{AR}^{10}$ \\
\hline $\begin{array}{l}\text { Location of } \\
\text { the calculus }\end{array}$ & $\begin{array}{l}\text { Lower pole renal calculi present worse results than } \\
\text { mid-pole and upper pole calculi. Calycine calculi } \\
\text { have worse outcomes compared to renal pelvic } \\
\text { and ureteral stones. }\end{array}$ & $\begin{array}{l}\text { Retrospective } \\
\text { cohort study }\end{array}$ & III & B & $\begin{array}{l}\text { Al Ansari } \\
\mathrm{A}^{18} \text { and Kanao } \\
\mathrm{K}^{21}\end{array}$ \\
\hline $\begin{array}{l}\text { Skin-to-stone } \\
\text { distance }\end{array}$ & Distances over $9 \mathrm{~cm}$ negatively affect ESWL & $\begin{array}{l}\text { Retrospective } \\
\text { cohort study }\end{array}$ & III & B & $\begin{array}{l}\text { Perks } \mathrm{AE}^{19} \text { and } \\
\text { Wiesenthal } \mathrm{JD}^{20}\end{array}$ \\
\hline $\begin{array}{l}\text { Anatomy of } \\
\text { the excretory } \\
\text { path }\end{array}$ & $\begin{array}{l}\text { Unfavorable anatomy (infundibulopelvic angle } \\
<90^{\circ} \text {, infundibular length }>3.0 \mathrm{~cm} \text { and } \\
\text { infundibular width of }<4-5 \mathrm{~mm} \text { ) negatively affect } \\
\text { ESWL }\end{array}$ & $\begin{array}{l}\text { Retrospective } \\
\text { cohort study }\end{array}$ & III & B & Elbahnasy ${ }^{22}$ \\
\hline $\begin{array}{l}\text { Kidney } \\
\text { anomalies }\end{array}$ & $\begin{array}{l}\text { Kidneys with congenital anomalies have lower } \\
\text { elimination rates }\end{array}$ & $\begin{array}{l}\text { Retrospective } \\
\text { cohort study }\end{array}$ & III & B & Al Ansari $A^{18}$ \\
\hline
\end{tabular}

nausea and vomiting were analyzed, as well as the need for analgesia and auxiliary procedures for elimination of the calculi. Eight randomized studies were identified, including a total of 876 patients divided into two groups: 453 with catheters and 423 without catheters. The result of the meta-analysis showed no significant difference between groups (RR 0.97, 95\% CI 0.91-1.03, $\mathrm{p}=0.27$ ). The incidence of steinstrasse in the catheter group was similar to the group without catheters, except in one study. Nevertheless, the incidence of lower urinary tract symptoms was much higher in patients with a catheter (RR 4.10, 95\% CI 2.21-7.61, $\mathrm{p}<0.00001)$. There was no significant difference in rates of hematuria, fever, infection, pain, nausea or vomiting, and need for analgesia or auxiliary procedures between the groups. It was concluded that double-J stenting prior to ESWL does not increase the rate of patients free from stones or reduce the need for auxiliary procedures, and boosts the presence of lower urinary tract symptoms.

In relation to care after ESWL, there is good evidence that drug treatment with alpha-blockers, specifically tamsulosin, provides benefits (Level of evidence: 1a; Grade of recommendation A). A recent meta-analysis has been published assessing the real efficacy of tamsulosin in patients undergoing ESWL, ${ }^{28}$ verifying that the drug increases the average calculus elimination rate by $16 \%(5$ to $27 \%$ ) and decreases calculus elimination time by 8 ( 3 to $20)$ days on average. Other medication such as nifedipi- ne have also proved effective as an adjunct to ESWL treatment, but with a higher rate of side effects such as dizziness and hypotension. ${ }^{29}$

\section{Complications}

A series of minor complications can occur after ESWL. Pain in the costovertebral angle and flank, the appearance of petechiae or subcutaneous bruising at the entry and exit point of the shock waves are common, requiring analgesics in up to $40 \%$ of cases. ${ }^{30}$ Microscopic hematuria occurs in virtually all cases, however gross hematuria appears only in about one third of patient. ${ }^{31} \mathrm{~A}$ prospective study of 3,241 patients with calculi larger than $4 \mathrm{~mm}$ undergoing ESWL (7,245 sessions) and monitored for a period of three months reported 4,075 complications, including renal colic (40\%), gross hematuria (32\%), urinary obstruction $(30.9 \%)$ and perirenal hematoma or subclinical subcapsular hematoma $(4.6 \%)$ as the most common. Furthermore, symptomatic bacteriuria was diagnosed in $9.7 \%$ of cases. ${ }^{32}$ Patients with pain are effectively treated with anti-spasmodic or anti-inflammatory drugs without further intervention required in most cases, such as repeated ESWL or ureteroscopy. Patients with gross hematuria present spontaneous improvement within 48 hours in $85 \%$ of cases, and in 10 days, in virtually $100 \%$ of cases. ${ }^{32}$ Patients with urinary obstruction can be clinically treated with alpha-blockers or surgically through double-J stenting or ure- 
teroscopy depending on the size, number and location of the calculi. Perirenal hematomas should be monitored with imaging exams and control of hemoglobin and hematocrit when large in size. Rare cases of post-ESWL renal explosion have been reported and even then a conservative treatment may be appropriate..$^{33}$ In a study of 6,172 ESWL sessions, Razvi et al..$^{34}$ evaluated the risk factors for the development of perirenal hematoma and identified intraoperative hypertension (hazard ratio $=$ $3.3,95 \%$ CI 1.6-10.2, $\mathrm{p}=0.03$ ) and use of anticoagulant/ antiplatelet agents (hazard ratio $=4.2,95 \%$ CI $1.1-15.9$, $\mathrm{p}=0.03)$ as significant.

In relation to late complications, a series of articles has sought to demonstrate an association between ESWL and the development of hypertension and diabetes. In a retrospective study of 727 patients undergoing ESWL, Chew et al. ${ }^{35}$ did not find a higher incidence of these diseases in the study group compared with the population mean. In a study of 4,782 patients with calculi and without hypertension monitored for an average of 8.7 years, Krambeck et al. ${ }^{36}$ also found no association between ESWL and hypertension in both univariate and multivariate analyses, including age, sex and obesity (hazard ratio $=1.03 ; 95 \%$ CI 0.8-1.2, $\mathrm{p}=0.77$ ). However, in a study with the collection of prospective data via a questionnaire sent to and answered by 2,041 patients undergoing ESWL, B arbosa et al. ${ }^{37}$ found a significant yet small increase in the incidence of hypertension in these patients compared to controls matched for age, sex and body mass index ( 37.8 versus $32.5 \%, \mathrm{p}=0.0009)$. In relation to the development of diabetes, a study with an identical design to the one mentioned above and with 1,869 patients submitted to ESWL did not find an increased incidence of diabetes in such patients compared to controls matched for age, sex and body mass index (5.2 versus $5.8 \%$; $\mathrm{p}=0.47) .{ }^{38}$ A study of 5,287 patients with calculi and without diabetes monitored for an average of 8.7 years found no association between ESWL and the appearance of diabetes in both univariate and multivariate analyses, including age, sex and obesity (hazard ratio $=0.92 ; 95 \%$ CI $0.71-1.18) .{ }^{39}$ The association between ESWL and the development of chronic diseases (hypertension and diabetes) is unclear and studies with higher levels of evidence are needed to confirm or rule out this association (Level of evidence $2 b$; Grade of recommendation B). Lastly, in relation to a possible worsening of renal function after ESWL, in a study of 156 patients with a single kidney undergoing ESWL and an average follow up of 3.8 years, El-Assmy et $a{ }^{40}$ found no changes in creatinine levels, demonstrating the safety of this method at least in the medium term (Level of evidence: 3; Grade of recommendation B).

\section{Conclusion}

ESWL shows good results in the treatment of kidney stones up to $2.0 \mathrm{~cm}$ and is an alternative to ureteroscopy in the management of ureteral calculi. Several technical factors are important for the optimization of results, and factors related to the patient and the stone, such as its size, density, skin to stone distance, anatomy of the excretory system and renal anomalies, help predict the chances of success. Antibiotic prophylaxis and double J stent placement before the procedure are not required. Alpha-blockers may increase success rates. Early and important complications are rare and late complications are not yet proven.

\section{Resumo}

Litotripsia extracorpórea no tratamento de cálculos renais e ureterais.

A utilização de certos princípios técnicos e a seleção de casos favoráveis podem otimizar os resultados da litotripsia extracorpórea por ondas de choques (LECO). O objetivo deste trabalho é revisar os princípios de funcionamento da LECO, suas indicações e contraindicações, fatores preditivos de sucesso e suas complicações. Realizou-se uma pesquisa na base de dados do Pubmed $^{\circledR}$ entre janeiro/1984 e outubro/2013 utilizando como palavras chaves shock wave lithotripsy e stone. Apenas artigos com bom nível de evidência, de língua inglesa, em seres humanos, do tipo clinical trials ou de revisão/metanálise foram incluídos. Na busca pela otimização dos resultados da LECO, diversos fatores técnicos, como o tipo de aparelho de litotripsia, energia e frequência dos pulsos, acoplamento do paciente ao litotridor, localização do cálculo e tipo de anestesia, devem ser levados em consideração. Fatores relacionados ao doente e ao cálculo, como seu tamanho, densidade, distância pele-cálculo, anatomia da via excretora e anomalias renais, também são importantes. A profilaxia com antibiótico não é necessária, e a passagem de duplo J de rotina não é recomendada. A prescrição de alfabloqueadores, particularmente a tansulosina, é benéfica em cálculos $>10 \mathrm{~mm}$. Complicações menores podem ocorrer após LECO e geralmente respondem bem a condutas clínicas. A relação entre LECO e o surgimento de hipertensão e diabetes não está comprovada.

Palavras-chave: litotripsia, cólica renal, ureter, cálculos urinários, cálculos renais. 


\section{REFERENCES}

1. Alanee S, Ugarte R, Monga M. The effectiveness of shock wave lithotripters: a case matched comparison. J Urol. 2010;184:2364-7.

2. Lambert EH, Walsh R, Moreno MW, Gupta M. Effect of escalating versus fixed voltage treatment on stone comminution and renal injury during extracorporeal shock wave lithotripsy: a prospective randomized trial. J Urol. 2010;183:580-4

3. Rassweiler JJ, Knoll T, Kohrmann KU, McAteer JA, Lingeman JE, Cleveland $\mathrm{RO}$ et al. Shock wave technology and application: an update. Eur Urol. 2011;59:784-96.

4. Li K, Lin T, Zhang C, Fan X, Xu K, Bi L, et al. Optimal frequency of shock wave lithotripsy in urolithiasis treatment: a systematic review and metaanalysis of randomized controlled trials. J Urol. 2013;190:1260-7.

5. Mazzucchi E, Brito AH, Danilovic A, Ebaid GX, Chedid Neto E, Azevedo JR, et al. Comparison between two shock wave regimens using frequencies of 60 and 90 impulses per minute for urinary stones. Clinics. 2010;65:961-5.

6. Pace KT, Ghiculete D, Harju M, Honey RJ, University of Toronto. Lithotripsy A. Shock wave lithotripsy at 60 or 120 shocks per minute: a randomized, double-blind trial. J Urol. 2005;174:595-9.

7. Pishchalnikov YA, Neucks JS, VonDerHaar RJ, Pishchalnikova IV, Williams JC Jr., McAteer JA. Air pockets trapped during routine coupling in dry head lithotripsy can significantly decrease the delivery of shock wave energy. J Urol. 2006;176:2706-10.

8. Jain A, Shah TK. Effect of air bubbles in the coupling medium on efficacy of extracorporeal shock wave lithotripsy. Eur Urol. 2007;51:1680-6.

9. Li G, Williams JC Jr, Pishchalnikov YA, Liu Z, McAteer JA. Size and location of defects at the coupling interface affect lithotripter performance. BJU Int. 2012;110:E871-7.

10. El-Nahas AR, El-Assmy AM, Mansour O, Sheir KZ. A prospective multivariate analysis of factors predicting stone disintegration by extracorporeal shock wave lithotripsy: the value of high-resolution noncontrast computed tomography. Eur Urol. 2007;51:1688-93.

11. Warner MA, Warner ME, Buck CF, Segura JW. Clinical efficacy of high frequency jet ventilation during extracorporeal shock wave lithotripsy of renal and ureteral calculi: a comparison with conventional mechanical ventilation. J Urol. 1988; 139: 486-7.

12. Cormack JR, Hui R, Olive D, Said S. Comparison of two ventilation techniques during general anesthesia for extracorporeal shock wave lithotripsy: highfrequency jet ventilation versus spontaneous ventilation with a laryngeal mask airway. Urology. 2007;70:7-10.

13. Sorensen C, Chandhoke P, Moore M, Wolf C, Sarram A. Comparison of intravenous sedation versus general anesthesia on the efficacy of the Doli 50 lithotriptor. J Urol. 2002;168:35-7.

14. Lingeman JE, Siegel YI, Steele B, Nyhuis AW, Woods JR. Management of lower pole nephrolithiasis: a critical analysis. J Urol. 1994;151:663-7.

15. Lindqvist K, Holmberg G, Peeker R, Grenabo L. Extracorporeal shock-wave lithotripsy or ureteroscopy as primary treatment for ureteric stones: a retrospective study comparing two different treatment strategies. Scand J Urol. 2006;40:113-8.

16. Picozzi SC, Ricci C, Gaeta M, Casellato S, Stubinski R, Ratti D, et al. Urgent shock wave lithotripsy as first-line treatment for ureteral stones: a metaanalysis of 570 patients. Urol Res. 2012;40:725-31.

17. Streem SB. Contemporary clinical practice of shock wave lithotripsy: a reevaluation of contraindications. J Urol. 1997;157:1197-203.

18. Al-Ansari A, As-Sadiq K, Al-Said S, Younis N, Jaleel OA, Shokeir AA. Prognostic factors of success of extracorporeal shock wave lithotripsy (ESWL) in the treatment of renal stones. Int Urol Nephrol. 2006;38:63-7.

19. Perks AE, Schuler TD, Lee J, Ghiculete D, Chung DG, D'A Honey RJ, et al. Stone attenuation and skin-to-stone distance on computed tomography predicts for stone fragmentation by shock wave lithotripsy. Urology. 2008;72:765-9.

20. Wiesenthal JD, Ghiculete D, Ray AA, Honey RJ, Pace KT. A clinical nomogram to predict the successful shock wave lithotripsy of renal and ureteral calculi. J Urol. 2011;186:556-62.
21. Kanao K, Nakashima J, Nakagawa K, Asakura H, Miyajima A, Oya M, et al Preoperative nomograms for predicting stone-free rate after extracorporeal shock wave lithotripsy. J Urol. 2006;176:1453-6.

22. Elbahnasy AM, Clayman RV, Shalhav AL, Hoenig DM, Chandhoke P, Lingeman JE, et al. Lower-pole caliceal stone clearance after shockwave lithotripsy, percutaneous nephrolithotomy, and flexible ureteroscopy: impact of radiographic spatial anatomy. J Endourol. 1998;12:113-9.

23. Tuckey J, Devasia A, Murthy L, Ramsden P, Thomas D. Is there a simpler method for predicting lower pole stone clearance after shockwave lithotripsy than measuring infundibulopelvic angle? J Endourol. 2000;14:475-8.

24. Sampaio FJ, DAnunciacao AL, Silva EC. Comparative follow-up of patients with acute and obtuse infundibulum-pelvic angle submitted to extracorporeal shockwave lithotripsy for lower caliceal stones: preliminary report and proposed study design. J Endourol. 1997;11:157-61.

25. Lu Y, Tianyong F, Ping H, Liangren L, Haichao Y, Qiang W. Antibiotic prophylaxis for shock wave lithotripsy in patients with sterile urine before treatment may be unnecessary: a systematic review and meta-analysis. J Urol 2012;188:441-8.

26. Kumar S, Sakthivel A, Chacko KN, Kekre NS, Ganesh G. Shock wave lithotripsy in solitary functioning kidneys: is prophylactic stenting necessary? Urol Int. 2006;77:179-81.

27. Shen P, Jiang M, Yang J, Li X, Li Y, Wei W, et al. Use of ureteral stent in extracorporeal shock wave lithotripsy for upper urinary calculi: a systematic review and meta-analysis. J Urol. 2011;186:1328-35.

28. Zhu Y, Duijvesz D, Rovers MM, Lock TM. Alpha-Blockers to assist stone clearance after extracorporeal shock wave lithotripsy: a meta-analysis. BJU Int. 2010;106:256-61.

29. Vicentini FC, Mazzucchi E, Brito AH, Chedid Neto EA, Danilovic A, Srougi M. Adjuvant tamsulosin or nifedipine after extracorporeal shock wave lithotripsy for renal stones: a double blind, randomized, placebo-controlled trial. Urology. 2011;78:1016-21.

30. Newman RC, Bezirdjian L, Steinbock G, Finlayson B. Complications of extracorporeal shock wave lithotripsy: prevention and treatment. Semin Urol. 1986;4:170-4

31. Sofras F, Karayannis A, Kostakopoulos A, Delakas D, Kastriotis J, Dimopoulos C. Methodology, results and complications in 2000 extracorporeal shock wave lithotripsy procedures. BJU Int. 1988;61:9-13.

32. Salem S, Mehrsai A, Zartab H, Shahdadi N, Pourmand G. Complications and outcomes following extracorporeal shock wave lithotripsy: a prospective study of 3.241 patients. Urol Res. 2010;38:135-42.

33. Marchini GS, Lopes RI, Bruschini H, Torricelli F, Lopes RN. Conservative treatment of severe renal trauma after extracorporeal shockwave lithotripsy. Rev Col Bras Cir. 2011;38:447-9.

34. Razvi H, Fuller A, Nott L, Méndez-Probst CE, Leistner R, Foell K, et al. Risk factors for perinephric hematoma formation after shockwave lithotripsy: a matched case-control analysis. J Endourol. 2012;26:1478-82.

35. Chew BH, Zavaglia B, Sutton C, Masson RK, Chan SH, Hamidizadeh R, et al. Twenty-year prevalence of diabetes mellitus and hypertension in patients receiving shock-wave lithotripsy for urolithiasis. BJU Int. 2012; 109:444-9.

36. Krambeck AE, Rule AD, Li X, Bergstralh EJ, Gettman MT, Lieske JC. Shock wave lithotripsy is not predictive of hypertension among community stone formers at long-term followup. J Urol. 2011;185:164-9.

37. Barbosa PV, Makhlouf AA, Thorner D, Ugarte R, Monga M. Shock wave lithotripsy associated with greater prevalence of hypertension. Urology. 2011;78:22-5.

38. Makhlouf AA, Thorner D, Ugarte R, Monga M. Shock wave lithotripsy not associated with development of diabetes mellitus at 6 years of follow-up. Urology. 2009;73:4-8

39. De Cógáin M, Krambeck AE, Rule AD, Li X, Bergstralh EJ, Gettman MT, et El. Shock wave lithotripsy and diabetes mellitus: a population-based cohort study. Urology. 2012;79:298-302.

40. El-Assmy A, el-Nahas AR, Hekal IA, Badran M, Youssef RF, Sheir KZ Long-term effects of extracorporeal shock wave lithotripsy on renal function: our experience with 156 patients with solitary kidney. J Urol. 2008;179:2229-32. 